\title{
MANAJEMEN RISIKO USAHA PEMBIBITAN TANAMAN BUAH DALAM PERKEMBANGAN USAHA MIKRO KECIL DAN MENENGAH DESA SUKAHATI (Study Kasus Di Kelompok Tani Tunas Hijau)
}

\author{
Resha Dennistian \\ Universitas Ibn Khaldun Bogor Jl. K.H. Soleh Iskandar Km. 2 Kedung Badak, Bogor \\ rdennistian@gmail.com
}

\begin{abstract}
Abstrak
Penelitian ini bertujuan untuk mengetahui bagaimana proses manajemen risiko pada kelompok tani Tunas Hijau dan tingkat efisiensi manajemen risiko yang dilakukan. Penelitian yang digunakan adalah kualitatif deskriptif. Hasil penelitian menunjukan bahwa secara umum proses manajemen risiko yang diberlakukan oleh kelompok tani Tunas Hijau sudah berjalan dengan baik namun belum efisien dari keseluruhan manajemen risiko yang dilakukan. proses manajemen risiko yang diterapkan oleh Kelompok Tani Tunas Hijau cukup sederhana dan mudah hanya saja membutuhkan perhatian yang lebih agar proses manajemen risiko tersebut bisa berjalan dengan baik. pendapatan para pengusaha yang berada di kelompok tani Tunas Hijau juga sangat berpengaruh dengan proses manajemen risiko yang diberlakukan oleh setiap masing-masing manajemen perusahaan. Hal ini mennjukan bahwa manajemen risiko sangat berpengaruh besar dalam tingkat pendapatan yang didapatkan oleh para petani yang ada di kelompok tani Tunas Hijau.
\end{abstract}

\section{Kata kunci: Manajemen Risiko, Tingkat Efisiensi, Pengaruh Pendapatan}

\begin{abstract}
This study aims to determine how the risk management process in the Tunas Hijau farmer group and the level of risk management efficiency is carried out. The research used is descriptive qualitative. The results showed that in general the risk management process implemented by the Tunas Hijau farmer group had run well but not yet efficient from the overall risk management carried out. the risk management process implemented by the Tunas Hijau Farmer Group is quite simple and easy, but it requires more attention so that the risk management process can run well. the income of entrepreneurs in the Tunas Hijau farmer group is also very influential with the risk management process imposed by each company management. This shows that risk management has a big influence on the level of income earned by farmers in the Tunas Hijau farmer group.
\end{abstract}

Keyword : Risk Management, Management Eficiency, Income

\section{PENDAHULUAN}

Usaha manusia dalam rangka mewujudkan kesejahteraan hidup umat manusia di muka bumi ini sangat berkaitan dengan urusan ekonomi. Dalam pandangan islam kegiatan ekonomi yang sesuai dan dianjurkan adalah melalui kegiatan bisnis dan investasi. (Pardiansyah, 2017) Kedua konsep tersebut merupakan alat penunjang pembangunan ekonmi yang memilik tujuan untuk mewujudkan tingkat pertumbuhan

Received: 2018-10-05 | Reviced: 2019-01-29 | Accepted: 2019-02-12

Indexed : DOAJ, Garuda, Crossref, Google Scholar | DOI: https://doi.org/10.29313/amwaluna.v3i1.4115 
dan memaksimalkan ekonomi umat dalam rangka menciptakan kesejahteraan lewat sistem ekonomi dan keuangan yang mempuni. Indonesia, negara yang memiliki ribuan pulau dan ratusan hektar lahan. Memiliki potensi yang sangat besar di dalam bidang agribisnis. Berdasarkan data yang dilansir oleh Kementrian dan Koperasi dan UMKM, Proyeksi jumlah UMKM yang berbasis pertanian, peternakan, pehutanan dan perikanan yaitu ada pada titik $48,85 \%$. (Aribawa, 2016) Ini menunjukan bahwa minat masyarakat indonesia di bidang Agribisnis sangat besar dan sangat berpotensi lebih untuk membantu Produk Domestik Bruto Indonesia. dengan kata lain, Potensi tingginya Jumlah penduduk Indonesia berbanding lurus dengan potensi perkembangan UMKM yang ada di indonesia. Respatiyo berpendapat dari sisi supply, indonesia memiliki potensi sumber daya alam yang luar biasa dari 191,7 juta hektar luas daratan. 133,7 hektar $(69,7 \%)$ berpotensi menjadi lahan pertanian, 22,4 juta hektar $(11,7 \%)$ sangat feasible untuk usaha pertanian tanaman pangan dan hortikultura. Potensi ini didukung pula dengan kekayaan plasma nutfah indonesia yang paling lengkap dan beragam di dunia, sehingga bisa dihasilkan beragam produk.

Data Badan Pusat Statistik menyatakan bahwa, pasca krisis ekonomi tahun 1997-1998 jumlah UMKM tidak berkurang, justru meningkat terus, bahkan mampu menyerap 85 juta hingga 107 juta tenaga kerja sampai tahun 2012. Pada tahun itu, jumlah pengusaha di indonesia sebanyak 56.539.560 unit atau 99,99\%. Sisanya, sekitar $0,01 \%$ atau 4.968 unit adalah usaha besar. Data tersebut membuktikan, UMKM merupakan pasar yang sangat potensial bagi industri jasa keuangan, terutama bank untuk menyalurkan pembiayaan. Karena sekitar 60-70\% pelaku UMKM belum memiliki akses pembiayaan perbankan. Pengalaman tersebut telah menyadarkan banyak pihak, untuk memberikan porsi lebih besar terhadap bisnis skala mikro, kecil, dan menengah. Pemerintah dan legislatif membuktikan perhatiannya terhadap UMKM dengan meluncurkan UU no. 20 Tahun 2008 tentang UMKM. Dengan adanya peraturan yang menjadi payung hukum, gerak UMKM menjadi semakin leluasa. Salah satu Bisnis yang di gemari oleh masyarakat indonesia adalah Agribisnis. Potensi sumber daya alam yang sangat besar memacu semangat beberapa pegiat UMKM untuk melakukan bisnis ini. Hanya saja beberapa pegiat UMKM terkadang masih kurang informasi tentang tata cara manajemen risiko yang baik. dan juga pada pengusaha pemula terkadang ragu untuk terjun langsung ke dalam dunia 
agribisnis dikarenakan menganggap bahwasanya dunia agribisnis sangat besar risiko nya sehingga para masyarakat yang baru ingin terjun ke dalam dunia UMKM sangat khawatir dengan berbagai risiko yang ada, karena pada dasarnya tidak ada satupun bisnis yang luput dari risiko kerugian dalam perjalanannya. Kekhawtiran yang sangat besar dari beberapa pengusaha yang ingin terjun di dunia Agribsinis ini yang menjadi acuan dari penelitian ini. Para pengusaha yang ingin terjun di dalam dunia Agribisnis namun masih ragu untuk terjun dikarenakan persepsi bahwa Agribisnis ini mempunyai risiko yang lumayan besar, yang bisa mengancam kelangsungan usaha suatu perusahaan.Padahal, potensi agribisnis khususnya di indonesia ini, mempunyai potensi yang cukup besar dalam membantu mengangkat GDP indonesia. Namun, Potensi yang besar ini berbanding lurus dengan besar nya manajemen risiko yang harus dihadapi. Minimnya literasi secara mendalam dan persepsi masyarakat terhadap usaha Agribisnis yang kurang menguntungkan dan memiliki risiko yang lumayan besar yang membuat masyarakat, terutama para pegiat UMKM yang ingin terjun langsung ke dunia Agrtibisnis ini enggan untuk menggeluti usaha di bidang Agribisnis. (Djojosoedarsono, 1999)
Agribisnis merupakan bisnis berbasis usaha pertanian ataug bidang lain yang mendukungnya, baik di sektor hulu maupun hilir, penyebutan hulu dan hilir megacu pada pandangan pokok bahwa agribisnis bekerja pada rantai sektor pangan (Food supply chain). Dengan kata lain, agrbisnis aadalah cara pandang ekonomi bagi usaha penyediaan pangan. Sebagai subjek akademik, agribisnis mempelajari strategi untuk memperoleh keuntungan dengan memperoleh keuntungan dengan mengelola aspek budidaya, penyediaan bahan baku, pascapanen, proses pengolaahan, hingga taahap pemasaraan. (Soekartawi, 2002)

Besarnya kekhawatiran masyarakat tentang risiko yang ada di dalam agribisnis dikarenakan kurangnya pengetahuan tentang manajemen risiko itu sendiri. Karena, organisasi bisnis pertanian dan petani lebih cenderung menghadapi risiko daripada sektor bisnis lainnya, Fakta bahwa produk dan jasa pertanian terkait dengan proes alam, aset biologis, dan tanaman dan penyakit hewan. Sektor pertanian sangat terkena dampak kejgadian alam yang merugikan, seperti kerusakan serangga atau kondisi cuaca yang buruk yang memiliki dampak negatif pada produksi. Kedepan perubahan ikllim bisa berlanjut lebih jauh dari peningkatan biaya ekonnomi dari bencana iklim utama. Oleh karena itu petani harus mengembangkan manajemen 
risiko strategi untuk mengatasi kejadian buruk dari bencana iklim. Di dalam industri pertanian juga sangat penting untuk mengevaluasi dan mengelola risiko yang sudah ada. (Darmawan,2005)

Dikarenakan industri agribisnis sanggat erat ketergantugannya terhadap cuaca dan iklim risiko. Salah satu nya adalah Kelompok Tani Tunas Hijau yang telah mempraktikan manajemen risiko didalam bidang agribisnis dengan sangat baik. (Darmawi, 2005) (Kasidi, 2010)

Kelompok Tani Tunas Hijau menjawab tantangan risiko yang dihadapi oleh pengusaha yang bergerak di bidang agribisnis dengan sangat baik.

Penelitian ini bertujuan untuk mengetahui bagaimana proses manajemen risiko serta tingkat efisiensi yang diberlakukan oleh kelompok tani Tunas Hijau dan pengaruh nya ke dalam pendapatan para pengusaha yang ada di kelompok tani Tunas Hijau.

Manajemen berasal dari kata to manage yang artinya mengatur. Pengaturan dilakukan melalui proses dan diatur berdasarkan urutuan dari fungsi-fungsi manajemen itu. jadi, manajemen itu merupakan suatu proses untuk mewujudkan tujuan yang diinginkan. Manajemen Menurut Ricky W. Griffin adalah sebuah proses perencanaan, pengorganisasian, pengordinasian dan pengontrolan sumber daya untuk mencapai sasaran secara efektif dan efisien. Dari definisi tersebut tampak ada beberapa pokok penting dalam definisi manajemen, yaitu adanya tujuan yang ingin dicapai, tujuan dicapai dengan mengggunakan sumber daya yang ada. Dan setiap kegiatan harus dibimbing dan diawasi. Yang menunjukan bahwa adanya komponen-komponen tersebut sangat penting dalam menunjang suatu manajemen di dalam perusahaan. Perencanaan berarti bahwa para manajer memikirkan kegiatankegiatan mereka sebelum dilaksanakan. Berbagai kegiatan ini biasanya didasarkan pada berbagai metoda, rencana atau logika, bukan hanya atas dasar dugaan atau firasat. Pengorganisasian berarti bahwa para manajer mengkoordinasikan sumber dayasumber daya manusia dan material organisasi (Malayu, 2011)

\section{Pengertian Risiko}

Risiko adalah ketidakpastian, yang dimaksud dengan ketidakpastian adalah tampaknya ada kesepakatan bahwa risiko berhubungan dengan ketidakpastian, yaitu adanya risiko, karena adanya ketidakpastian. Risiko juga adalah kemungkinan kerugian. Kemungkinan kerugian yang dimaksud adalah dampak yang terjadi jika risiko tersebut terjadi pada suatu perusahaan dan perusahaan tersebut tidak menjalankan manajemen risiko yang baik. maka besar kemungkinan risiko 
tersebut akan terjadi dikarenakan pada perusahaan tersebut tidak menerapkan manajemen risiko yang baik, itulah yang disebut risiko sebagai kemungkinan kerugian. (Kertonegoro, 1996)

\section{Pengertian Manajemen Risiko}

Secara sederhana pengertian manajemen risiko adalah pelaksanaan fungsi-fungsi manajemen dalam penanggulangan risiko, terutama risiko yang dihadapi oleh organisasi atau perusahaan, keluarga dan masyarakat. Jadi mencakup kegiatan merencanakan, mengorganisir, menyusun, memimpin atau mengkoordinir dan mengawasi (termasuk mengevaluasi) program penanggulangan risiko. Program manajemen risiko dengan demikian mencakup tugas-tugas mengidentifikasi risiko-risiko yang dihadapi, mengukur atau menentukan besarnya risiko tersebut, mencari jalan untuk menghadapi atau menanggulangi risiko, selanjutnya menyusun strategi untuk memperkecil ataupun mengendalikan risiko, mengkoordinir pelaksanaan penanggulangan risiko serta mengevaluasi program penanggulangan risiko

Manajemen Risiko adalah sejumlah kegiatan atau proses manajemen yang terarah dan bersifat proaktif, yang ditujukan untuk mengakomodasi kemungkinan gagal pada salah satu, atau sebagian dari sebuah transaksi atau instrumen. Karena itu manajemen risiko haruslah merupakan sebuah proses yang dinamis, tidak statis, dan berubah sejalan dengan perubahan kebutuhan dan risiko usaha. Sementara menurut Abbas Salim Risiko adalah ketidakpastian yang mungkin melahiran kerugian. (Kasidi, 2010)

\section{Perspektif Islam atas Manajemen}

\section{Risiko}

Risiko Perspektif Islam (Wahyudi, 2013) dalam pengelolaan risiko suatu organsiasi dapat dikaji dari kisah Yusuf dalam mentakwilkan mimpi sang raja pada masa itu. Kisah ini termaktub dalam Qur'an sebagai berikut:

“ (Setelah pelayan itu berjumpa dengan Yusuf dia berseru): "Yusuf, hai orang yang amat dipercaya, terangkanlah kepada kami tentang tujuh ekor sapi betina yang gemukgemuk yang dimakan oleh tujuh ekor sapi betina yang kurus-kurus dan tujuh bulir (gandum) yang hijau dan (tujuh) lainnya yang kering agar aku kembali kepada orang-orang itu, agar mereka mengetahuinya." QS: Yusuf: 46.

"Yusuf berkata: "Supaya kamu bertanam tujuh tahun (lamanya) sebagaimana biasa; maka apa yang kamu tuai hendaklah kamu biarkan dibulirnya kecuali sedikit untuk kamu makan. QS: Yusuf : 47. 
"Kemudian setelah itu akan datang tahun yang padanya manusia diberi hujan (dengan cukup) dan dimasa itu mereka memeras anggur." QS: 12: 49

\section{Tujuan Manajemen Risiko}

Tujuan manajemen risiko adalah untuk menekan akibat merugikan dari risiko murni dengan biaya minimum, sesuai dengan tujuan perusahaan. Pengukuran dan pengidentifikasian yang tepat dan sesuai. Akan membuat sebuah perusahaan siap dalam menghadapi segala macam risiko yang dihadapi dalam setiap kegiatannya. Terlebih kepada pelaku usaha agribisnis yang sangat rentan dalam berbagai risiko yang mungkin bisa saja dapat terjadi kapan saja. Dengan melakukan identifikasi risiko dan mengetahui betul bagaimana pentingnya manajemen risiko tersebut maka kemungkinan-kemungkinan risiko yang akan datang akan dapat dihadapi dengan baik. manajemen risiko yang baik dapat membantu perusaahaan menghindari semaksimal mungkin biaya-biaya yang terpaksa harus dikeluarkan, di samping itu dapat dipertahankannya ketenangan pegawai dalam bekerja. (Fasa, 2017)

\section{Karakterisitik UMKM}

UMKM memiliki karakteristik tertentu yang bisa yang membedakan antara yang satu dengan yang lain. UMKM merupakan sifat atau kondisi faktual yang melekat pada aktifitas usaha maupun perilaku pengusaha yang bersangkutan dalam menjalankan bisnisnya. Karakteristik ini yang menjadi ciri pembeda antar pelaku usaha sesuai dengan skala usahanya. Menurut Bank Dunia, UMKM dapat dikelompokkan dalam tiga jenis, (Huda, 2010) yaitu: 1. Usaha Mikro (jumlah karyawan 10 orang); 2. Usaha Kecil (jumlah karyawan 30 orang); dan 3. Usaha Menengah (jumlah karyawan hingga 300 orang). Dalam perspektif usaha, UMKM (Indonesia, 2015) diklasifikasikan dalam empat kelompok, yaitu:

1. UMKM sektor informal, contohnya pedagang kaki lima.

2. UMKM Mikro adalah para UMKM dengan kemampuan sifat pengrajin namun kurang memiliki jiwa kewirausahaan untuk mengembangkan usahanya.

3. Usaha Kecil Dinamis adalah $\mathrm{k}$ elompok UMKM yang mampu berwirausaha dengan menjalin kerjasama (menerima pekerjaan sub kontrak) dan ekspor.

4. Fast Moving Enterprise adalah UMKM yang mempunyai kewirausahaan yang cakap dan telah 
siap bertransformasi menjadi usaha besar.

Pada Table 2.1 akan dijelaskan mengenai kllasifikasi Usaha Mikro Kecil dan Menegah menurut UU No.20 Tahun 2008 tentang UMKM:

Tabel 1.. Kriteria UMKM \&Usaha Besar Berdasarkan Aset dan Omset

\begin{tabular}{|l|c|c|}
\hline \multirow{2}{*}{$\begin{array}{c}\text { Ukuran } \\
\text { Usaha }\end{array}$} & \multicolumn{2}{c|}{ Kriteria } \\
\cline { 2 - 3 } $\begin{array}{l}\text { Usaha } \\
\text { Mikro }\end{array}$ & $\begin{array}{c}\text { Maksimal } \\
\text { Rp 50 } \\
\end{array}$ & $\begin{array}{c}\text { Maksimal } \\
\text { Jp 300 } \\
\text { Juta }\end{array}$ \\
\hline IIUsaha & $>$ Rp 50 & $>$ Rp 300 \\
Kecil & Juta - Rp & Juta - Rp \\
& 500 Juta & 2,5 Miliar \\
\hline Usaha & $>$ Rp 500 & $>$ Rp 2,5 \\
Menengah & Juta - Rp & Miliar - \\
& 10 Miliar & Rp 50 \\
& & Miliar \\
\hline Usaha Besar & $>$ Rp 10 & $>$ Rp 50 \\
& Miliar & Miliar \\
\hline
\end{tabular}

Sumber: UU No.20/2008

\section{METODE}

Metode penelitian yang digunakan adalah metode kualitatif yaitu metode yang dikaitkan dengan pengumpulan dan analisis data yang menyadarkan pada pemahaman, dengan penekanan pada makna-makna yang terkandung atau yang ada di balik kenyataan-kenyataan yang teramati. Analisis yang digunakan analisis deskriptif, yang artinya penyelidikan yang menuturkan, menganalisa, dan mengklasifikasi penyelidikan dengan teknik survey, wawancara, angket, serta observasi

\section{PEMBAHASAN}

Manajemen perusahaan dalam kelompok tani tunas hijau memiliki beberapa cara dalam menanggulangi beberapa ancaman risiko yang akan menimpa perusahaan tersebut. Sebagai contoh, dalam menanggulangi sumbersumber risiko seperti, risiko sosial, fisik dan ekonmi. manajemen tunas hijau memiliki beberapa cara agar ancaman risiko tersebut tidak terjadi kepada sebuah perusahaan, dan jika kemungkinan terburuknya itu terjadi, maka kerugian yang menimpa tidak begitu besar. Dan ini ditanggulangi berdasarkan sumber-sumber risiko yang ada.

1) Dalam mengatasi sumber risiko sosial beberapa manajemen perusahaan yang berada di tunas hijau, melakukan sweeping setiap malam dan menseleksi secara ketat sumber daya manusia yang akan di rekrut sebagai karyawan. Dalam hal ini, kelompok tani tunas hijau lebih memilih sumber daya manusia yang berasal dari garut dikarenakan pengetahuannya tentang agribisnis sudah mumpuni, tunas hijau tidak mengambil sumber daya manusia ddari daerah sekitar dikarenakan minat warga sekitar yang masih tidak mau untuk bekerja sebagai petani agribisnis. 
Ditambah lagi, warga sekitar tidak mau jika bekerja nya menginap di tempat kerja. Selain itu para manajemen perusahaan yang ada di tunas hijau membuat peraturanperaturan yang disepakati oleh masingmasing karyawannya. Hal ini dilakukan agar sumber risiko sosial bisa teraatasi dengan baik.

2) Dalam mengatasi sumber risiko fisik, beberapa manajemen perusahaan yang ada di tunas hijau mempunyai caranya tersendiri agar sumber risiko fisiko bisa terminimalisir dengan baik. Dalam meminialisir Risiko Fisik ini, tunas hijau mencari lahan yang strategi untuk dijadikan tempat usahanya kelak, dan lahan itu tepat di dekat sungai ciliwung, tepatnya lahan yang dijadikan lahan untuk memulai usaha dibidang agribisnis ini hanya berjarak beberapa meter saja dari bibir sungai ciliwung, pemilhan lahan ini bukanlah tanpa didasari oleh alasan. Melainkan pihak manajemen tunas hijau menilai bahwasanya risiko fisik ini harus diminimalisir secara baik. pemilihan lahan usaha berdekatan dengan sungai bertujuan agar stabilitas air untuk kelangsungan usaha bisa teratasi dengan baik. karena, salah satu tantangan terbesar yang dihadapi oleh pelaku usaha di bidang agribisnis adalah kekeringan atau kemarau panjang. Jadi, pemilihan lahan berdekatan dengan sungai merupakan pilihan yang sangat tepat dan sangat membantu untuk kelangsungan usaha ini. Pemilihan lahan yang berdekatan dengan sungai juga merupakan sebuah langkah untuk meminimalisir ancaman risiko-risiko yang ada. Seperti kebakaran dan gempa bumi.

3) Dalam meminimalisir kemungkinan risiko ekonomi manajemen risiko dalam tunas hijau lebih mengutamakan kesehatan bibit-bibit tanaman yang di kembangbiakan, dan juga bagaimana bibit-bibit tanaman ini terawat dengan baik. karena, harga didalam penjualan produk agribisnis sangat fluktuatif tergantung dari tingkat kondisi dari bibit tanaman itu sendiri jika bibit yang dijual tidak bagus, maka harga nya pun akan turun drastis. Namun, Tunas Hijau dapat meminimalisirkan hal itu dengan baik

Metode pengidentifikasian Risiko dalam melakukan pengidentifikasian risiko, tunas hijau memiliki beberapa cara agar dapat mengidentifikasikan ancaman risiko yang akan terjadi kedepannya. Diantaranya adalah :

1) Menggunakan pertanyaan

Para pengusaha membuat sedikit peertanyaan yang bertujuan untuk mengetahui ancaman apa saja yang kelak akan dihadapinya. Dari jawaban pertanyaan-pertanyaan tersebut diharapkan dapat memberikan petunjuk-petunjuk 
tentang risiko yang menyangkut kekayaan maupun operasi perusahaan.

2) Berkunjung langsung ke lokasi

Artinya dengan mengadakan pemeriksaaan langsung ke tempat dimana dilakukan operasi atau aktivitas perusahaan sehingga dari pengamatan itu manajer akan dapat belajar kenyataan-kenyataan lapangan, yang akan sangat bermanfaat bagi upaya penanggulangan risiko. ini yang dilakukan para pengusaha di tunas hijau. Yaitu melakukan inspeksi langsung ketempat yang ingin dijadikan tempat usaha. Dari sana, para pengusaha dapat menilai langsung. Bagaimana kontur tanah, pengaliran air dan sekeliling tempat usaha itu sendiri. Jadi jika ada sesuatu yang bisa mengancam kelangsungan usaha para pengusaha ini dapat dengan mudah mengetahuinya karena sebelumnya melakukan proses pengidentifikasian risiko ini. Karena dalam bidang agribisnis dalam memilih lahan sangat penting para pengusaha harus jeli dengan lingkugan sekitar. apakah tempat itu bisa mendukung opreasional perusahaan atau tidak.

\section{Langkah-langkah Pelaksanaan}

Dalam Pelaksanaanya pengusaha di tunas hijau memiliki langkah-langkah untuk melakukan pengelolaan risiko nya. Agar seluruh operasional perusahaan berjalan dengan baik Berikut adalah alur proses pelaksaaan manajemen risiko yang dilakukan oleh Kelompok Tani Tunas Hijau

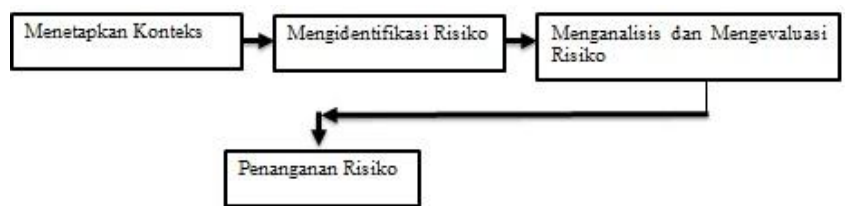

Gambar 1.

Alur Proses Pelaksanaan Manajemen

Risiko Kelomok Tani Tunas Hijau

Dalam Pelaksanaanya pengusaha di tunas hijau memiliki langkah-langkah untuk melakukan pengelolaan risiko nya. Agar seluruh operasional perusahaan berjalan dengan baik Berikut adalah alur proses pelaksanaan manajemen risiko yang dilakukan oleh Kelompok Tani Tunas Hijau:

1) Menetapkan konteks

Konteks ini adalah tujuan perusahaan atau biasa yang disebut dengan visi dan misi perusahaan. Para pengusaha di tunas hijaumemiiki visi dan misinya masingmasing agarsetiap perusahaan memiiki tujuan yang jelas.

2) Mengidentifikasi risiko

Dalam pengaplikasiannya, tunas hijau melakukan identifikasi risiko menggunakan dua cara yaitu pertanyaan dan inspeksi langsung. salah satu yang sering digunakan adalah identifikasi melalui pertanyaan what, when, where, why dan how berkaitan dengan keecenderugan munculnya risiko. 
Tentu saja para pengusaha di tunas hijau melakukan metode ini. Karena semakin lengkap data yang dikumpulkan dalam proses identifikasi ini, maka akan semakin mudah dalam mencari solusi bagi pengendalain setiap risiko yang muncul. Tunas hijau juga menggunakan metode inspeksi langsung, dimana para pengusaha ini melakukan inspeksi ke lapangan atau tempat yang ingin dijadikan tempat usaha, agar para pengusaha tahu kira-kira risiko apa yang akan muncul dari tempat usahanya tersebut. Metode ini sangat bagus digunakan terlebiih di dalam bidang agribisnis. Mengingat banyak pengusaha yang memasrahkan jalannya operasional perusahannya pada seorang manajer.

3) Menganalisis dan Mengevaluasi Risiko

Setelah pengidentifikasian risiko, selanjutnya Tunas hijau menentukan tingkat pengendalian terhadap risiko-risiko tersebut dengan mempertimbangkan tingkat kemungkinan serta kosekuensinya terhadap tingkat risiko. Dalam hal ini para pengusaha di tunas hijau mendiskusikannya dengan karyawanya. Menurut ruslan, hal itu sangat perlu dilakukan karena terkadang para karyawan mempunyai pengetahuan yang lebih, atau saran-saran yang baik untuk jalannya sebuah perusahaan. Proses ini membantu memahami kemungkinan terjadinya risiko beserta dmpak dari setap risiko bila nantinya benar-benar terjadi, serta mengetahui apabila suatu risiko dapat diterima atau tidak. Dalam hal ini pengusaha di tunas hijau menemukan beberapa risiko yang bisa di analisis secara bersama, seperti risiko sosial, ekonomi, risiko fisik. Semua kemungkinan risiko ini dikumpulkan dan dan di analisis bagaimana cara penangananya oleh para pemilik perusahaan dan karyawannya masingmasing.

4) Penanganan Risiko

Permasalahan dari tahap ini adalah menentukan priotitas penanganan terhadap risiko-risiko yang ada. Disini kebijakan manajemen dan pimpinan perusahan berperan sangat penting dalam pengambilan keputusan ini. Para pengusaha ditunas hijau lebih memprioritaskan risiko fisik dan risiko ekonomi karena menurut Ruslan, risiko fisik dan risiko ekonomi sangat berpengaruh besar dalam jalannya usaha terutama dalam bidang agribisnis. Seperti penentuan tempat usaha, penaganan bibit, perawatan bibit tanaman, publikasi para perusahaan di tunas hijau. Hal-hal itu yang lebih diprioritaskan terlebih dahulu oleh para pimpinan perusahaan dikarenakan pertimbangan-pertimbangan tingkat risiko yang akan terjadi dalam perusahaan tersebut. Sehingga dalam praktiknya, perusahaan yang bernaung di dalam 
kelompok tani tunas hijau dapat menangani tingkat risiko dengan baik.

Efisiensi manajemen Risiko Kelompok Tani Tunas hijau dalam pelaksanaanya, manajemen risiko yang dipraktekan oleh kelompok tani tunas hijau masih belum efektif ini ditunjukan dari fakta yang ditemukan di lapangan bahwanya beberapa kasus pencurian masih saja terjadi, dan masih belum bisa bersaing di dalam era digital yang sangat berkembang pesat pada saat ini. Manajemen tunas hijau masih belum bisa bersaing di dalam persaingan bisnis secara digital. Masih perlu beberapa pebaharuan yang dilakukan oleh kelompok tani tunas hijau agar beberpa kelemahan yang masih ada diperusahaan tidak terjadi secara signifikan. Di dalam menghadapi era digital ini, Manajemen Perusahaan Tunas Hijau juga ingin adanya pembaharuan dikarenakan persaingan usaha yang semakin ketat, menutut para pengusaha berfikir secara lebih dan luas untuk mencari cara agar dapat bersaing dalam era digital ini. Penjualan secara online dan website saja belum cukup. Menurut ruslan, harus ada Inovasi baru agar dapat bersaing secara penuuh dengan pesaing usaha serupa lainnya. argumen ini di berikan atas dasar berkembang nya era digitaal yang ada di indoesia. Menjamurnya E-Commerce, dan beberapa financial technology yang membangun bisnisnya dalam koridor agribisnis, jelas memaksa setiap pengusaha dalam bidang yang sama harus bersaing dengan teknologi. Itu yang masih menjadi evaluasi dan yang harus dikikirkan dan dikembangkan lagi oleh tunas hijau. Didalam menghadapi sumber risiko ekonomi ini tunas hijau menganggap tidak perlu adanya pembaruan, melainkan hanya pengawasan yang perlu ditingkatkan lebih. Dikarenakan tingkat kenaikan harga dalam bidang agribisnis bisa diakali dengan beberapa cara. Dari membuat bibit sendiri, membuat pupuk sendiri. Sehingga perusahaan dapat menekan biaya produksi yang ada jika beberapa aspek seperti bibit dan pupuk dapat dibuat dan di jual belikan sendiri oleh tunas hijau. Dalam praktiknya tunas hijau memiliki produk andalan yaitu bibit pohon alpukat, dan bibit pohon tjambu kristal. Setiap tahunnya para pengusaha di tunas hijiau menjual 20.000 bibit jika dikalkulasikan maka, setiap tahunnya kelompok tani tunas hijau menjual 500.000 bibit tanaman buah ke seluruh indonesia. ini menenunjukan bahwasanya tunas hijau bisa meminimalisir tingkat sumber risiko yang mengancam. Karena menurut Tunas Hijau, dalam bidang agribisnis jika bibit yang dihasilkan merupakan bibit yang secara kualitas baik. maka harga dalam pasaran pun semakin baik. ditambah lagi para pengusaha di tunas hijau dapat 
memproduksi sendiri bibit dan pupuk yang mana akan menekan biaya produksi dari masing masing perusahaan. Sudah dipastikan bahwa dalam sumber risiko ekonomi sejauh ini kelompok tani tunas hijau dapat menanggulanginya dengan baik. sehingga pengawasan yang baik sajalah yang dibutuhkan pengusaha di tunas hijau agar dapat konsisten dalam meminimalisir tingkat risiko ekonomi yang ada.

\section{Pengaruh Pendapatan Pengusaha}

\section{Dengan Penerapan Manajemen Risiko}

Manajemen risiko yang di terapkan oleh para pimpinan perusahaan yang ada di tunas hijau, sangat memiliki pengaruh besar dalam jalannya operasional perusahaan terkait. Menurut ruslan, sudah ada beberapa contoh yang kongkrit jika manajemen risiko tidak diterapkan secara benar dan berlanjut. Seperti contohnya, dalam pemeliharaan bibit kesalahan kecil seperti lupa menyiram bisa berakibat fatal dikarenakan tanaman yang tumbuh juga bisa tumbuh tidak secepat yang ditargetkan alhasil ongkos biaya produksi nya pun bertambah. Lalu jika para pengusaha tidak memerhatikan dengan baik tempat usahanya maka itu akan berpengaruh sangat besar bagi kelangsungan usaha tersebut. Contohnya, di dalam memilih lahan usaha, jika para calon pengusaha yang mau terjun dibidang agribisnis dan tidak memerhatikan kondisi lahan nya dengan baik maka bisa dimungkinkan risiko risiko yang tak terduga bisa menimpa perusahaan tersebut. Menurut Ruslan, faktor yang mempengaruhi pendapatan dengan managemen risiko adalah cara perawatannya saja. Selebihnya para pengusaha yang berada di tunas hijiau telah melakukannya dengan baik. iini terbukti dengan hasil-hasil produk bibit yang dikeluarkan oleh tunas hijau, sangat bagus dan memiliki kualiltas yang sangat baik. ini diperkuat oleh argumen Rodi Kusnaidi seorang sekretaris desa sukahati menuturkan bahwa perekonomian warga sukahati terus membaik semenjak mayoritas warganya bertani bibit buah. Dikarenakan permintaan akan bibit tanaman buah semakin meningkat sehingga banyak masyarakat desa sukahati yang beralih ke bidang agribisnis. Ini membuktikan pola manajemen risiko yang diterapkan dengan baik oleh tunas hijau berdampak kepada banyaknya permintaan pasar bogor maupun luar bogor terhadap bibit tanaman buah ini. Inii membuktikan bahwa kualitas yang dimiliki oleh para petani tanaman bibit buah ini sangat bagus dan patut diperhitungkan di dalam persaingan pasar. Karena, jika kualitas nya buruk berarti permintaan pasar hanya sedikit dan tidak konsisten. Manajemen 
risiko yang di terapkan oleh para pimpinan perusahaan yang ada di tunas hijau, sangat

\section{SIMPULAN}

Berdasarkan hasil penelitian yang telah dilakukan, maka penulis dapat menyimpulkan beberapa hal sebagai berikut: (1)Secara umum Kelompok Tani Tunas Hijau telah mengaplikasikan sistem manajemen risiko dengan sangat baik. semua aspek-aspek didalam manajemen risiko telah diterapkan dengan baik oleh kelompok tani tunas hijau. Adapun dari segi peraturan dan disiplin yang diterapkan oleh para pimpinan perusahaan tunas hijau sudah dipraktekan dengan baik oleh para karyawan dan manajemen. sumber risiko dan ancaman yang mengancam operasional perusahaan yang ada di tunas hijau sudah ditangani dengan baik, meski masih ada beberapa sumber risiko yang lolos dalam penangan manajemen risiko kelomppok tani tunas hijau. (2)Tingkat efisiensi dari manajemen risiko yang diterapkan oleh kelompok tani tunas hijau belum efisien. Adapun faktor yang menyebabkan manajemen risiko kelompok tani tunas hijau belum efisien dan masih perlu pembaharuan diantaranya, Persaingan usaha yang begitu ketat dan perkembangan teknologi yang semakin pesat serta pengawasan yang harus diberikan secara ekstra dalam meminimalisir risiko-risiko yang ada.
3. Berkembangnya pendapatan masyarakat desa sukahati yang mayoritas pengusaha tanaman bibit buah ini, menunjukan bahwa peluang bisnis yang ditawarkan dalam bisnis ini cukup besar. Diharapkan pemerintah dapat memberikan lahan yang lebih kepada pengusaha yang bergerak dibidang agribisnis agar gerak laju bisnis para pegusaha ini dapat ternaungi dengan baik dengan adanya bntuan danri pemerintah.

\section{DAFTAR PUSTAKA}

Aribawa, D. (2016). "Pengaruh literasi keuangan terhadap kinerja dan keberlangsungan UMKM di Jawa Tengah. Jurnal Fakultas Hukum UII $20.1,1-13$.

Darmawi, H. (2005). Manajemen Risiko. Jakarta: Bumi Aksara.

Djojosoedarsono, S. (1999). Prinsip-prinsip Manajemen Risiko dan Asurans. Jakarta: Salemba Empa.

Fasa, M. I. (2017). Manajemen Resiko Perbankan Syariah di Indonesia. $\mathrm{Li}$ Falah: Jurnal Studi Ekonomi dan Bisnis Islam 1.2 , 36-53.

Firdaus, M. A. ( 2016). Metodologi Penelitian Edisi 2. Tangerang: Jelajah Nusa.

Foster. (1984). Manajemen Perusahaan. Jakarta, Erlangga. 
Fuad, e. a. (2001). Pengantar Bisnis. Jakarta: Gramedia Pustaka Utama.

Heinz, P. (2010). Risk Management: Procedurs, Methods, and Experiences.

Huda, N. d. (2010). Lembaga Keuangan Islam. Jakarta: Pranedia Media Group.

Indonesia, L. d. (2015). Profil Bisnis Usaha Mikro, Kecil dan Menengah. Jakarta.

Kasidi. (2010). Manajemen Risiko. Bogor: Ghalia Indonesia.

Kertonegoro, s. (1996). Manajemen Risiko dan Asuransi. Jakarta: Toko Gunung Agung.

Malayu. ( 2011). Manajemen Dasar, Pengertian, dan Masalah. Jakarta: PT Bumi Aksara.

Moleong, J. L. (2012). Metodologi Penelitian Kualitatif. Bandung: PT Remaja Rosdakarya.

Pardiansyah, E. (2017). Investasi dalam Perspektif Ekonomi Islam: Pendekatan Teoritis dan Empiris. Economica: Jurnal Ekonomi Islam 8.2, 337-373.

Pranama, T. (2011). Manajemen Risiko Bisnis. Jakarta: Sinar Ilmu Publishing.

Siagian, R. (2003). Yogyakarta: Gadjah Mada Unversity Press.
Soekartawi. (2002). Prinsip Dasar Manajemen Pemasaran Hasil-Hasil Tani Teori danAplikasinya. Jakarta: PT Raja Grafindo Utama.

Sugiyono. (2014). Memahami Penelitian Kualitati. Bandung: Alfabeta.

Surakhmad, W. (1982). Pengantar Ilmiah Dasar Metoda Teknik. Bandung: Tarsito.

Tampubolon, R. ( 2004). Manajemen Risiko Pendekatan Kualitatif Untuk Bank Komersial. Jakarta: Elexmedia Komputindo.

Tanjung, H. d. (2013). Metode Penelitian Ekonomi ISLAM. Jakarta: Gramata Publishing.

Umar, H. (1998). Manajemen Risiko Bisnis Pendekatan Finansial dan Nonfinansia. Jakarta: Gramedia Pustaka Utama.

Wahyudi, I. e. (2013). Manajemen Risiko Bank Islam. Jakarta: Salemba Empat.

William Nickels, e. a. (2009). Pengantar Bisnis. Jakarta: Salemba Empa. 